\title{
SLAVE RESISTANCE AND DECOLONIZING CARIBBEAN HISTORY IN ANDREA LEVY'S THE LONG SONG
}

Tia Byeri

MSc in United States Literature and Cultural Values, Department of Literatures, Languages \& Cultures, The University of Edinburgh, United Kingdom

\begin{abstract}
:
Set during the final days of Slavery on the island of Jamaica, Andrea Levy's 2010 novel, The Long Song is a neo-slave narrative that explores the nature of slave resistance and colonial historiographical control. ${ }^{\text {ii }}$ When read through a postcolonial lens, The Long Song takes the form of a counter-discourse, where the main character of Miss July offers a corrective to the dominant white narratives of Caribbean history. This essay argues that the experience of resistance in Levy's narrative is one of literary mimicry, analysing July's written resistance as it answers back to and confronts the colonial narratives that disregard the oppressed individual experience from history. Levy, in reanimating the history of Jamaican slavery by aligning her text with the unheard 'History From Below' perspective, demonstrates and replicates the unreliable narratives orchestrated by those 'From Above'. As such, both Levy and her fictional July employ a method of historiographic metafiction to reclaim the previously silenced voice of the Jamaican slaves that the hegemonic White Planter class seek to oppress and obliterate from historical record.
\end{abstract}

Keywords: metafiction, Caribbean writing, Caribbean history, historiographic metafiction, postcolonialism

\section{Introduction}

Slave resistance in Levy's text The Long Song is one of literary counter-discourse (2010). Shakespeare foregrounds the possibility of using enforced colonial discourse to rebuke colonial rule and exploitation through the character of Caliban, in The Tempest. For instance, the slave Caliban claims, "you taught me language, and my profit on't is, I know how to curse" (Shakespeare, 1611, Act 1, Scene 2,44). Communication becomes a weapon in The Long Song when Levy's fictional narrator writes back to the white colonial historical narratives about the Caribbean. In particular, the postcolonial experience in the text reveals how former slaves are marginalized victims of historical narratives that deny them accurate representation and the ability to voice their own "story" (Levy, 1). The outspoken "Miss July" operates as a female Caliban within the

\footnotetext{
${ }^{i}$ Correspondence: email tiabyer.inquiries@gmail.com
} 
text. July self-consciously reveals her intent to resist the totalising narratives from history through unveiling the falsity with which they exist and promote. In particular, she employs a deliberately artificial narrative that is an act of historiographic metafiction- the term Lynda Hutcheon uses to describe literature demonstrating "theoretical self-awareness of history and fiction as human constructs" $(1988,5)$. July replicates the unreliability of historic narrative to undermine colonial logic.

Communication becomes an act of subordination in the foreword to July's fictional narrative where July's son and her "publisher-editor", Thomas Kinsman contextualises July's 'will' and authorial intent as a counter-discourse (Levy, 4). For instance, July's tale will become, he writes, a "fable [that] would never be lost and ... might gain mastery to rival the legends told whilst pointing at the portraits or bust in any fancy great house upon this island of Jamaica" (1). Here, the ability to communicate through history is exclusively the white man's privilege. The juxtaposition between solid enduring 'legends' and the fragility of oral tradition, demonstrates the dominance of the white historical narrative. Thomas insists that July's tale produce a lasting "legacy of a printed book" as opposed to taking the form of "words" that would be lost in Caribbean history (4 and 2). The noun 'rival' implies that tales such as July's recount of her "harsh circumstances" of "slavery", contend with narratives produced from whom the busts are modelled; the colonial master (1 and 214).

Bill Ashcroft, Gareth Griffiths and Helen Tiffin, in their ground-breaking text, The Empire Writes Back claims that in postcolonial literature there is a radical critique of the "distinctiveness of the world system perspective" derived from Eurocentric notions of language and literature (2002, 13). July's narrative is narrated at a time "when every slave upon this island did shake of their burden of their bondage as one" (Levy, 182). The unifying postcolonial experience as communicated here in Levy's text, when read in conjunction with Ashcroft et al, communicates and exposes a postcolonial alienation caused by the void between "experience of place and the language available to describe it" (9). By asserting and revealing the tension inherent in the assumptions of the imperialist Eurocentric centre, the voices of former colonies "write back" (6). They respond to the homogeneous historical 'legac[ies]' produced "for all in England to Read", that are almost always voiced by those who ensure and implement colonisation. The 'busts' from which the 'legends' derive, historically dominate (Levy, 6).

The preposition 'upon', describing how 'legends' about the history of the Caribbean originate from emblems of lasting control visible 'in any fancy great house upon this island of Jamaica', connotes seizure. The master's house and presence is an imposed structure; it is not natural to the island. This is emblematic of the white man's tendency to impose a Eurocentric order onto the Caribbean, both in terms of slavery and logic. White structuring metaphors of eurocentrism are not succinct with the Caribbean as a place; they sit uncomfortably and squash. The fact that the coloniser's house sits 'on' the island, in an elevated position demonstrates the authority with which they exist, and the confidence with which the white planter class change and abuse the land. The non-specificity of which exact coloniser the historic 'bust's' and 'legends' refer to, as indicated by his determiner 'any', implies that communicative privilege through history is universal to the white planter class as well as totalising in the effect it produces. Alison Donnell and Lawson Welsh argue that the Caribbean as "a history, a geography and a people...has 
been dominated by British Victorians- both literally and literarily" (1996, 4). Historical narratives belong to the planter class. As a result of this, the slaves' perspective appears to be non-existent. Silence is another 'harsh circumstance' of slavery within the text. Thomas explains how: "My mama began her life as a person for whom writing...letters...could have seen her out to the lash" (Levy, 3). An inability to communicate furthers the slave's oppression and demonstrates how educating slaves was considered dangerous for colonial power dynamics (and was usually illegal) (Dabydeen, 1985, 26-50). The issue of communication in a postcolonial context is foregrounded by Spivak who asked famously asked: "Can the Subaltern Speak?" $(1983,25)$. To be a subaltern is to belong to the economic underclass, where colonial power dynamics determine who can communicate and who cannot. Silence is synonymous with oppression and speech is indicative of power. Associated with the 'History From Below' movement, Spivak discusses how historically, it might have been strategic to talk for someone or provide a voice for people who traditionally have been denied one. Despite the fact that July is born into a moment of silence, when her mother Kitty is gagged during childbirth, July is born, "a squealing, a tempestuous, fussmaking child", who "yell[s]" and is "constant[ly] screeching" (Levy, 21). As such, July is brought into the world to challenge the structures of oppression that have abused her mother. Susan Alice Fischer argues that Levy "unearth[s] and recuperate[s] silenced and marginalized lives [...] to place these experiences at the forefront" $(2014,111)$. In birthing July, Kitty is enabled a means by which to voice her story of enslavement. July's text will decolonize Caribbean history. History and storytelling will not be told "on [her] behalf" anymore (Levy, 195). In particular, Andrea Stuart argues that July's narrative "acts as an important corrective to the dominant representation of this subject" of the Caribbean's history of colonialism (2010, n.p.). The historical "void", that Franz Fanon describes in The Wretched of the Earth, will be filled by her act of 'writing back' $(1963,58)$.

Historically speaking, the 'void' exists as a result inaccurate hegemonic white accounts of the Caribbean experience that disvalues the slave's Caribbean experience. July claims, "there are plenty of books to satisfy if words flowing free as the droppings that fall from the backside of a mule is your desire" (Levy, 8). This metaphor demonstrates the worthless nature of such accounts; they do not communicate meaningful historical fact. The recorded "meanderings" of the "white lady's mind" lack weight; they are superficial " $p u f f$ " (8). Levy's diction here, is an onomatopoeic representation of the irrelevance of 'white lady's' account, that for July is full of air and absent of any actual meaning. In particular, the "daft white missus [']" account of discomfort experienced in colonial Jamaica lacks objectivity (8). July mocks the need for, as she put it "three chapters [...] to lament upon a white woman of discerning mind who finds herself adrift in a society too dull for her" (8). Here, the White planter class's written transmittance of suffering during colonialism is disproportionate. In recorded history the mere 'discomfort' felt from 'above', takes precedent over the "injustice" experienced by the subaltern (21).

According to Spivak, to challenge the colonial imperatives of political domination is to speak out. July professes to being "a woman possessed of a forthright tongue and little ink" (7). In chapter 1, July communicates her intent to "squash" the European values used to justify imperial control and that have since been perpetuated by the "ornate invention" of these historical accounts (8). The "annoying" bug acts as an analogue of colonialism and July's process of 'writing back' (9). For example, the "insistent" trouble it causes July as it "distracting[ly] [...] throw[s] itself" 
against the lamp, as indicated through the "repeat[ed]" onomatopoeic "buzzing" sound, suggests that the insect is an antagonist to July's peace (9). Religious connotations evident the way it is drawn to the lamp as "the light is where salvation lies", echoes historic justification for slavery (9). Slavery was justified according to the notion that the European would civilize the African (Dabydeen, 26). In particular, one of Levy's listed archive sources, the infamous gothic novelist of The Monk (1796), and heir to several Jamaican plantations, Mathew Lewis, calls himself "master Noah" $(1818,58)$. Lewis in his autobiographical, Journal of a West Indian Proprietor, views himself as a "steward" to his slaves and it is his sense of "morality" as 'master' that aligns him with the biblical "righteous man" of Genesis. July's counter-narrative will put an end to these values and justifications. The connotations of violence evoked by the "bloody carcass" that the murdered insect creates on the page, demonstrates the means by which July will ensure her own 'curse' upon her former oppressors (Levy, 9). Written communication in the form of a "book" will be how July exacts her revenge (9).

Audre Lorde in 1984 argued, "the master's tools will never dismantle the master's house"(1). This claim implies the impossibility of Caliban's mockery and July's authorial intent. July's narrative, however, does enable her to resist the colonial imperatives that determines who can speak. In particular, she exhibits agency when she ends her subordination to the homogenising accounts that depict what Levy calls an "untruth" (296). July responds directly to the colonial values evidenced within the so-called "official" account her son's adoption (193). A deliberate manipulation of history occurs in the published article of Thomas' adoptive mother, "the wife of the baptist minister-man -the saintly, good-godly Jane Kinsman" (193). July charges Jane Kinsman's "printed" essay describing the event, as a "fancifully" written misrepresentation (195). The essay claims that upon being questioned about whether her son was born in "wedlock", July replied; "him was born in de wood-where be wedlock?" (195). July contests what was previously seen as the "truth" communicated by historical archives by insisting, "July said no such fool-fool thing" (193 and 195). Here, July renders her recorded ignorance to be false. The Kinsman's motivation behind the adoption also comes under scrutiny. Levy writes; "'the salvage of the savage' was Mr Kinsman's mission" in that "he believed that even the blackest Negro could be turned from sable heathen into a learned man, under his and God's tuteledge" (188). Kinsman is invested in the same imperial 'call' for 'salvation' that Lewis is and that Dabydeen identifies as that which necessitated the repeated assertion that "blacks were ignorant" (29). In writing back and challenging their values, July remains insubordinate to the historical tradition of being spoken for.

July deconstructs the stereotype of the 'ignorant' slave by enacting colonial mimicry. For Homi Bhabha, mimicry is a "strategic objective" that creates a "metonymy of presence" (1994, 89). Mimicry is a tool by which to subvert and deconstruct colonial ideology. The opportunist process allows the colonial subject to expose colonial contradiction and consequently "reform the Other as a subject of difference that is almost the same but not quite" (126). July replicates the unreliability of the 'recorded' white planter class's version of history, within her own narrative. Levy exemplifies July's knowledge of how historical fact and fabrication become intertwined in historical narratives. The textual revision she commits in reference to the day "colonial slavery died" illustrates this (Levy, 195). The narrative initially professes that "July [...] walked within this procession" but later admits that "July was not [actually] skipping joyous with the celebration" (195). 
In revealing how her own narrative "purport[s] to be a fiction", July demonstrates what Hutcheon identifies as typical of historiographic metafiction (397). This genre, Hutcheon argues, communicates a distinction between "events" and "facts" (231). Historical knowledge is semiotically transmitted whereby historians interpret and transmute historical documents, as fact. However, historical documentation is a sign of events; they contain no meaning in themselves as facts are given meaning. July's deconstruction demonstrates her vast knowledge. Mimicry as a form 'storytelling' facilitates July's insubordination whereby in performing similarity, according to the coloniser's standards of difference, July resists the stereotype of the 'ignorant' slave.

In The Long Song, historiographic metafiction is two-fold. Both July and Levy mimic the unreliability inherent in the hegemonic historical narratives documenting the Caribbean. Roland Barthes in his 1967 'The Death of the Author' essay claimed that consideration of authorial intent during textual interpretation "is to impose upon that text a stop-clause" and a limit (n.p.). However, understanding Levy's neo-slave narrative as a deliberate fictional counter-discourse provides, as Sean Burke later claims in his direct counter to Barthes; "a necessary [...] condition of the existence of objective meaning" in a text (n.p.). The Long Song's paratext - the bibliography Levy describes as acknowledging the "great many other minds" associated with "Jamaica during the nineteenth century" - establishes a self-awareness of Levy's own novel to be "story ... more thrilling than anything the rascal spider Anancy could conjure" (399 and 13). In Caribbean folklore African figure of Anansi is a trickster. Taking the form of a 'spider-king' and a lovable rogue, Anansi, and by extension, Anansi-stories became synonymous with survivalist methods of usurpation (Marshall, 2018, 59). Therefore, mimicry and trickery in The Long Song allows Levy to challenge conventional understanding of historical fact by reanimating lost histories. In revealing its own artifice, Levy's text and July's fictional tale demonstrate how the external reality presented by the historical sources listed, is similarly fabricated.

To conclude, July resists by exposing how former slaves have been marginalized in the wider historical narratives of the white planter class. By employing a counter-discourse with a vengeful 'curse' in literary mimicry, the subaltern's tale, like the figure of Anansi, can survive. When an accurate view from 'below' becomes lost in history due to continual misrepresentation and silencing, only an act of communicative insubordination can fill that 'historical void'. Both Levy and July fashion their written resistance around a metafictional conceit in order to undermine that which seeks to silence July in a postcolonial context. As such, insubordination allows July and Levy to deconstruct and resist definition according to the reality Eurocentric culture impose onto former colonial subjects.

\section{Conflict of Interest Statement}

The author declares no conflicts of interests.

\section{About the Author}

Tia Byer is an Associate Editor and freelance journalist specialising in culture and lifestyle reporting. Tia holds an MSc in US Literature and Cultural Values from the University of Edinburgh, and a BA (Hons) in English Literature from York St John University. She has 
published research on topics covering Native American literature, The American Renaissance, Transatlanticism, and Caribbean literature and song. For an extensive list of her publications please visit https://tiabyer.journoportfolio.com/.

\section{References}

Ashcroft B et al., 2002. The Empire Writes Back: Theory and Practice in Post-Colonial Literatures. London, Routledge.

Barthes R, 1967. "The Death of the Author", Available from https://sites.tufts.edu/english292b/files/2012/01/Barthes-The-Death-of-the-Author.pdf (Accessed 27th May 2021).

Bhabha H, 1994. The Location of Culture. London, Routledge.

Dabydeen D, ed., 1985. "Eighteenth-Century English Literature on Commerce and Slavery," in The Black Presence in English Literature. Manchester, Manchester University Press.

Donnell A and Lawson Welsh S, ed., 1996. The Routledge Reader in Caribbean Literature. London, Routledge.

Fanon F, 1963. The Wretched of the Earth. New York, Grove Weidenfeld.

Fischer S A, 2014. "At the Centre of the Picture: Andrea Levy's The Long Song", in: Baxter J and James D, eds., Andrea Levy: Contemporary Critical Perspectives. London, Bloomsbury: pp. 109-121.

Genesis 6:9-9:17

Hutcheon L, 1988. A Poetics of Postmodernism: History, Theory, Fiction. New York, Routledge.

Levy A, 2010. The Long Song. London, Headline Publishing Group.

Lewis M, 1796 (repr. 2016). The Monk. Oxford, Oxford University Press.

Lewis M, 1818 (repr. 2008). Journal of a West Indian Proprietor. New York, Cosimo Press.

Lorde A, 1984 (repr. 2018). The Master's Tools Will Never Dismantle the Master's House. London: Penguin.

Marshall E, 2018. "'Nothing but Pleasant Memories of the Discipline of Slavery': The Trickster and the Dynamics of Racial Representation," Marvels $\mathcal{E}$ Tales 32, no. 1: pp. 58-198.

Shakespeare W, 1661 (repr. 1994). The Tempest. Ware, Wordsworth Classics.

Spivak G C, 1983. "Can the Subaltern Speak?", in: Ashcroft et al, eds., The Post-Colonial Studies Reader. London, Routledge: pp.28-38.

Stuart A, 2010. “The Long Song, By Andrea Levy," Independent, 5 February 2010. Available from www.independent.co.uk/arts-entertainment/books/reviews/the-long-song-by-andrealevy-1889489.html (Accessed 27th May 2021). 
Tia Byer

SLAVE RESISTANCE AND DECOLONIZING CARIBBEAN HISTORY IN ANDREA LEVY'S THE LONG SONG

Creative Commons licensing terms

Author(s) will retain the copyright of their published articles agreeing that a Creative Commons Attribution 4.0 International License (CC BY 4.0) terms will be applied to their work. Under the terms of this license, no permission is required from the author(s) or publisher for members of the community to copy, distribute, transmit or adapt the article content, providing a proper, prominent and unambiguous attribution to the authors in a manner that makes clear that the materials are being reused under permission of a Creative Commons License. Views, opinions and conclusions expressed in this research article are views, opinions and conclusions of the author(s). and European Journal of Literature, Language and Linguistics Studies shall not be responsible or answerable for any loss, damage or liability caused in relation to/arising out of conflicts of interest, copyright violations and inappropriate or inaccurate use of any kind content related or integrated into the research work. All the published works are meeting the Open Access Publishing requirements and can be freely accessed, shared, modified, distributed and used in educational, commercial and non-commercial purposes under a Creative Commons Attribution 4.0 International License (CC BY 4.0).

European Journal of Literature, Language and Linguistics Studies - Volume 5 | Issue 1 | 2021 